ISSN 0258-7122 (Print), 2408-8293 (Online)

Bangladesh J. Agril. Res. 44(1): 69-78, March 2019

\title{
DEVELOPMENT OF ALTERNATE CROPPING PATTERN MUSTARD - BORO -T.AMAN AGAINST FALLOW - BORO- T. AMAN IN KUSHTIA REGION
}

\author{
M. S. RAHMAN ${ }^{1}$ AND M. T. ISLAM ${ }^{2}$
}

\begin{abstract}
The experiment was conducted at Kushtia Sadar, Bheramara and Gangni Multi Location Testing (MLT) sites under On-Farm Research Division (OFRD), BARI, Kushtia (AEZ 11) during the last week of July to second week of May for three consecutive years (2013- 14, 2014-15 and 2015-16) to develop alternate cropping pattern (Mustard-Boro -T.Aman) and to compare its productivity and profitability against farmer's existing cropping pattern (Fallow - Boro-T.Aman). The mustard (var: BARI Sarisha-14), Boro rice (var: BRRI dhan28) and T.Aman (var: Binadhan-7) were used in alternate cropping pattern, while BRRI dhan28 for Boro rice and BRRI dhan39/Sorna for T.Aman rice were used in the existing cropping pattern. Findings revealed that the mean crop duration of alternate cropping pattern ranged 269-287 days by inclusion of mustard. Rice equvalent yield of alternate cropping pattern was $13.98 \mathrm{t} \mathrm{ha}^{-1}$ year ${ }^{1}$ which was $34 \%$ higher than that of existing pattern $\left(10.47 \mathrm{t} \mathrm{ha}^{-1} \mathrm{year}^{-1}\right)$. Land use efficiency (76.44\%) and labour employment (441 mandays ha $^{-1}$ year $^{-1}$ ) of alternate cropping pattern were 33 and $26 \%$, higher, respectively than those of existing cropping pattern. The mean gross return (Tk. 2,53,960 ha-1) and gross margin (Tk. 99,513/ha) of alternate cropping pattern were 29 and 32\%, respectively higher compared to those of existing cropping pattern (Gross return: Tk. 1,97,346 ha-1 and Gross margin: Tk. 75,340 ha-1) due to inclusion of high yielding variety of mustard. Therefore, farmers in Kushtia region of Bangladesh could follow alternate cropping pattern in their high and medium high land where lands remain fallow after harvesting of T. Aman rice for higher crop productivity and profitability.
\end{abstract}

Keywords: Grain yield, production efficiency, rice equvalent yield, profitability

\section{Introduction}

Bangladesh has achieved a remarkable progress in increasing food production. Agriculture sector contributes about $17 \%$ to the country`s Gross Domestic Product (GDP) and employs more than 45\% of total labour force (BBS, 2018). At present total cultivable land of the country is 8.44 million hectares and it is shrinking day by day. There are some scopes of increasing cropping intensity (192\%) by improving the existing cropping patterns by inclusion of short

${ }^{1}$ Senior Scientific Officer (Agricultural Economics), Regional Agricultural Research Station, Bangladesh Agricultural Research Institute (BARI), Jashore, ${ }^{2}$ Scientific Officer, Pomology Division, Horticulture Research Centre, BARI, Gazipur. 
duration crops viz., mustard, potato, mungbean and T.Aus rice in the rice based cropping system (Mondal et al., 2015).

Kushtia and Meherpur district is located under Agro Ecological Zone (AEZ) 11. The soil is calcareous under High Ganges River Floodplain. The cropping intensity of this area is $263 \%$ and about $93 \%$ lands are under irrigation (DAE, 2016). About $76 \%$ lands are under high and medium high land in which $20 \%$ lands remains fallow after harvesting of T.Aman rice.

Bangladesh Rice Research Institute (BRRI) has recommended the T.AmanMustard-Boro cropping pattern for the irrigated ecosystem (BARC, 2001; Khan et al., 2004) with the inclusion of 70-75 days local mustard (var. Tori-7) in between T. Aman and Boro rice. But the farmers harvest poor yield from local var. Tori7 that can be increased by introducing high yielding varieties (Alam and Rahman, 2006; Basak et al., 2007). Bangladesh Agricultural Research Institute (BARI) has developed high yielding mustard varieties, BARI Sarisha-14 and BARI Sarisha-15, respectively and has been recommended for T. AmanMustard-Boro cropping sequence (Mondal et al., 2011). Crop duration of BARI developed short duration mustard varieties is 75-85 days, whereas BRRI and BINA has developed short/medium duration rice varieties. With this view, the present study was, therefore, undertaken to develop Mustard-Boro -T.Aman rice cropping pattern and to compare its productivity and profitability against farmer's existing cropping pattern Fallow - Boro-T.Aman rice; and to determine the land use efficiency, production efficiency and labour employment generation of alternate and existing cropping pattern.

\section{Materials and Methods}

The experiment was conducted at Kushtia Sadar, Bheramara and Gangni Multi Location Testing (MLT) sites under On-Farm Research Division (OFRD), BARI, Kushtia (AEZ 11) during the last week of July, 2013 to second week of May, 2016 at farmers' field condition. The experiment was laid out in block approach where two blocks were used. Unit block size was one hectare per pattern. There were seven dispersed replications with two treatments i.e., alternate cropping pattern (Mustard-Boro-T.Aman) and farmer's existing cropping pattern (FallowBoro-T.Aman). In the alternate cropping pattern (ACP), the variety BARI Sarisha-14 for mustard, BRRI dhan 28 for Boro rice and Binadhan-7 for T.Aman rice was cultivated. While, in the existing cropping pattern $(\mathrm{ECP})$, the variety BRRI dhan 28 for Boro rice was used in all sites but in T.Aman rice BRRI dhan39 and Sorna rice varieties were used at Bheramara, and Kushtia Sadar and Gangni, respectively. The trial was started by T.Aman rice cultivation. Because lands remain fallow after harvesting of Boro rice which help to plan three crops in a piece of land in a year. Fertilizer management and intercultural operations like weeding, mulching, irrigation and pest management were done according to Mondal et al. (2011) and BRRI (2013). Transplanting was done with 27-28 days old seedling of rice var. Binadhan-7 for alternate cropping pattern and BRRI 
dhan39 and Sorna for existing cropping pattern at a spacing $20 \mathrm{~cm} \mathrm{x} 15 \mathrm{~cm}$ during 21-29 July for ACP and 05-10 August for ECP (Table 1). T.Aman rice was harvested during 27 October- 02 November for ACP and 16-22 November for ECP in three consecutive years. Mustard (var: BARI Sarisha-14) seed was sown in broadcasting method during 30 October - 6 November and harvested during 25 January -2 February in ACP. Mustard seed was sown in broadcasting method due to minimize labour cost of farmers. Boro rice seedling was transplanted with spacing $20 \mathrm{~cm} \times 15 \mathrm{~cm}$ during 28 January -7 February for ACP and 20 January -5 February for ECP. Seedling ages were 40-45 and 42-48 days old for ACP and ECP, respectively. Boro rice was harvested during 01-13 May in ACP and 06-20 May in ECP. In Boro and T.Aman rice, stem borer and sheath blight was observed in some plots. Folicur @ $0.5 \mathrm{ml} / \mathrm{L}$ was sprayed to control sheath blight and Virtako 40 WG @ 1.5g/10 L for stem borer. In Mustard, Rovral-50wp @ $2 \mathrm{~g} / \mathrm{L}$ was sprayed at early stage for controlling alternaria blight disease. All field operations and management practices of both alternate and existing cropping patterns were closely monitored and the data were recorded for observing agro-economic performance. The yield data of product and by-product were recorded. Grain/seed and straw yields of all rice and mustard as well as price data of inputs and outputs were taken timely.

Agronomic performance viz., land use efficiency, production efficiency and rice equivalent yield of cropping patterns were calculated.

Land use efficiency: It is worked out by taking total duration of individual crop in a pattern divided by 365 days as Tomer and Tiwari (1990) as follows:

$$
\text { Land use efficiency }=\frac{\sum d i}{365} \times 100
$$

Where,

$$
\mathrm{di}=\text { duration of the } \mathrm{i}^{\mathrm{th}} \text { crop } \mathrm{i}=1,2,3 \text { and } 4
$$

Production efficiency: Production efficiency in terms of $\mathrm{kg} \mathrm{ha}^{-1} \mathrm{day}^{-1}$ was calculated by total production in a cropping pattern divided by total duration of crops in that pattern (Tomer and Tiwari, 1990).

$$
\text { Production efficiency }=\frac{\sum Y i}{d i}
$$

Where,

$$
\begin{aligned}
& Y i=\text { Yield of the } i^{\text {th }} \text { crop } \\
& \text { di }=\text { duration of the } i^{\text {th }} \text { crop } i=1,2,3 \text { and } 4
\end{aligned}
$$

Rice equivalent yield: For comparison between cropping patterns, the yield of all crops was converted into rice equivalent yield (REY) on the basis of prevailing market price of individual crop (Verma and Modgal, 1983). 
Rice equivalent yield $\left(\mathrm{t} \mathrm{ha}^{-1}\right)=\frac{\text { Yield of individual crop } \times \text { Market price of that crop }}{\text { Market price of rice }}$

Profitability analysis: The economic indices like total variable cost and gross return were also calculated on the basis of prevailing market price of the produces. For economic evaluation of two tested cropping patterns, average data of three crop cycles were used. Gross return was calculated on the basis of taka per hectare of product and by-product. Total variable cost of different crops was calculated on the basis of taka per hectare of different operations performed and materials used for raising the crops.

\section{Results and Discussion}

Crop management: Crop management practices include date of sowing/transplanting, date of harvesting, fertilizer dose used, irrigation, weeding and application of pesticides etc. of alternate and existing cropping pattern are shown in Table 1. The mean crop (field) duration of mustard, Boro and T.Aman rice under alternate cropping pattern (Mustard-Boro-T.Aman rice) were 78-88, 96-99 and 95-100 days, respectively while, in existing cropping pattern (FallowBoro-T.Aman rice) were 100-107 days for Boro and 102-108 days for T.Aman. Total crop duration of ACP and ECP were 269-287 and 202-215 days, respectively. The crop duration of T.Aman rice under ECP was higher (102-108 days) than that of ACP (95-102 days) due to use high crop durated Sorna variety in ECP. Mustard did not cultivate in ECP due to late transplanting of T.Aman rice which was harvested on 16-22 November. Late sowing of mustard yielded lower and it is not economically viable. But in ACP, short duration of T.Aman rice (Binadhan-7) was cultivated and it was harvested during 27 October - 02 November. After harvesting of T.Aman rice mustard was easily sown in optimum period. Turn around times for ACP and ECP were 77-96 and 143-176 days, respectively.

Seed/Grain yield: The mean seed/grain yield of mustard, Boro and T.Aman were $1.26,5.30$ and $4.79 \mathrm{t} \mathrm{ha}^{-1}$, respectively in alternate cropping pattern while in existing cropping pattern Boro and T.Aman rice grain yields were 5.74 and $4.44 \mathrm{t}$ $\mathrm{ha}^{-1}$, respectively (Table 2). In alternate cropping pattern, mustard seed yield of Gangni was the highest $\left(1.39 \mathrm{t} \mathrm{ha}^{-1}\right)$ and it followed by Kushtia $\left(1.25 \mathrm{t} \mathrm{ha}^{-1}\right)$ and Bheramara $\left(1.15 \mathrm{t} \mathrm{ha}^{-1}\right)$. The grain yields of Boro rice were 5.40, 5.49 and $5.60 \mathrm{t}$ $\mathrm{ha}^{-1}$ for Kushtia, Bheramara and Gangni, respectively. T.Aman grain yield of Gangni was the highest $\left(5.26 \mathrm{t} \mathrm{ha}^{-1}\right)$ and it followed by Bheramara $\left(4.92 \mathrm{t} \mathrm{ha}^{-1}\right)$ and Kushtia $\left(4.18 \mathrm{t} \mathrm{ha}^{-1}\right)$. The mean straw yield of mustard, Boro and T.Aman were $1.71,5.43$ and $5.00 \mathrm{t} \mathrm{ha}^{-1}$, respectively in alternate cropping pattern while in existing cropping pattern Boro and T.Aman rice grain yields were 5.48 and $4.83 \mathrm{t}$ $\mathrm{ha}^{-1}$, respectively. 


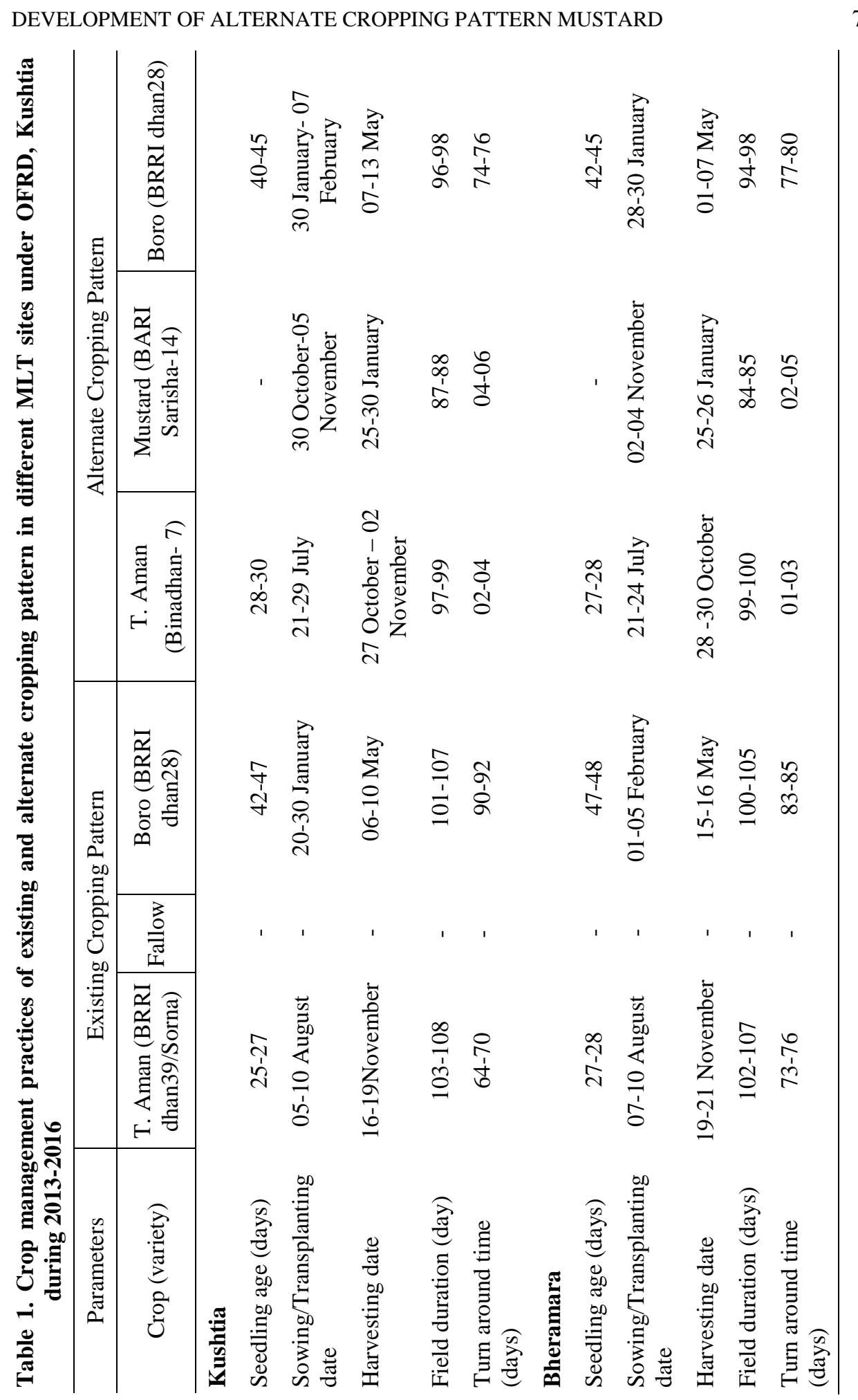




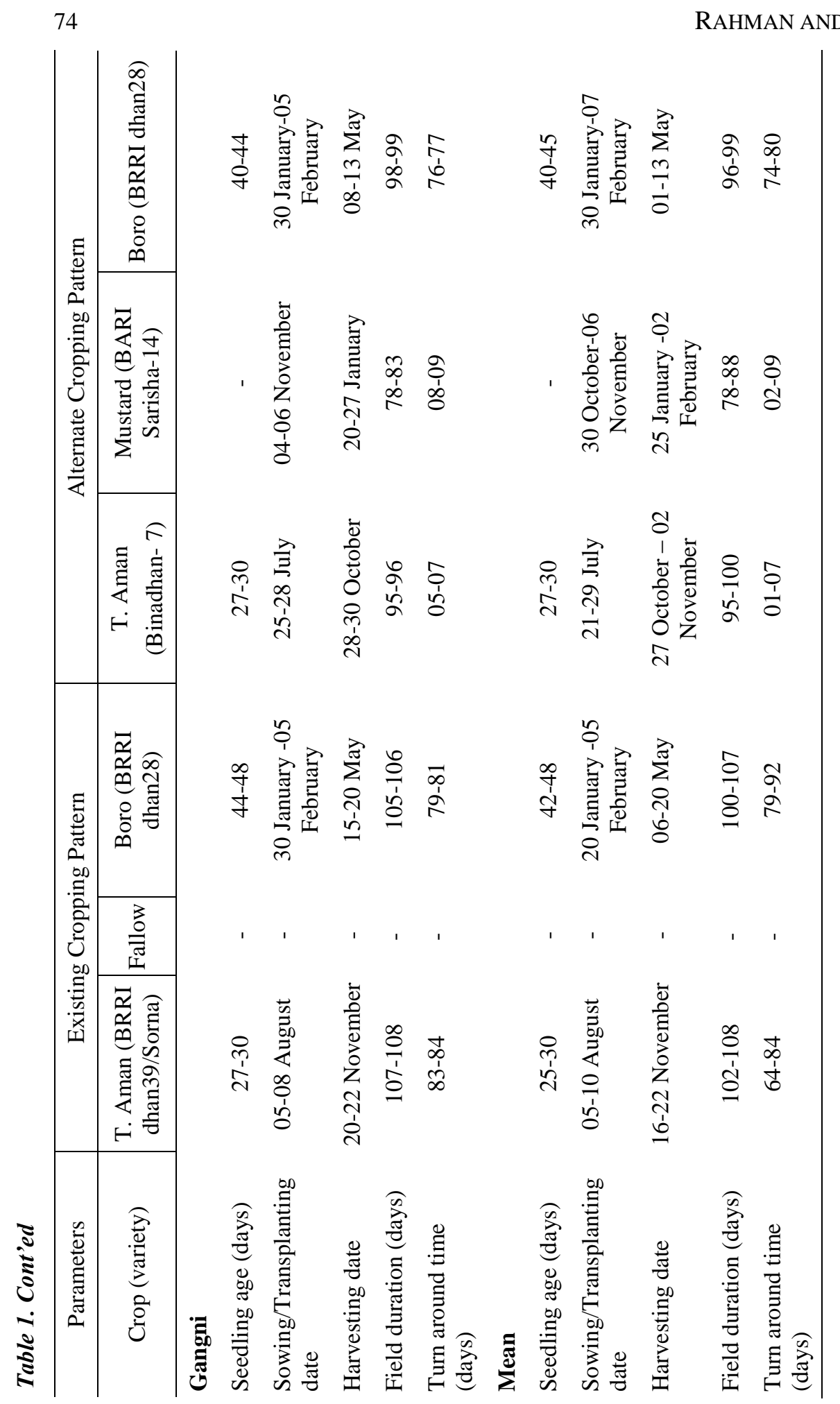


Table 2. Yield of alternate and existing cropping pattern in different MLT sites under OFRD, Kushtia during 2013-2016

\begin{tabular}{|c|c|c|c|c|c|c|}
\hline \multirow{2}{*}{$\frac{\text { Parameters }}{\text { Crop (variety) }}$} & \multicolumn{3}{|c|}{ Existing Cropping Pattern } & \multicolumn{3}{|c|}{ Alternate Cropping Pattern } \\
\hline & $\begin{array}{c}\text { T. Aman } \\
\text { (var. } \\
\text { BRRI } \\
\text { dhan39/ } \\
\text { Sorna) }\end{array}$ & Fallow & $\begin{array}{c}\text { Boro } \\
\text { (var. } \\
\text { BRRI } \\
\text { dhan28) }\end{array}$ & $\begin{array}{c}\text { T. Aman } \\
\text { (var. } \\
\text { Binadhan- 7) }\end{array}$ & $\begin{array}{c}\text { Mustard } \\
\text { (var. BARI } \\
\text { Sarisha-14) }\end{array}$ & $\begin{array}{c}\text { Boro (var. } \\
\text { BRRI } \\
\text { dhan28) }\end{array}$ \\
\hline \multicolumn{7}{|c|}{ Seed/grain yield (t ha' $\left.{ }^{-1}\right)$} \\
\hline Kushtia & 4.30 & - & 5.70 & 4.18 & 1.25 & 5.40 \\
\hline Bheramara & 4.22 & - & 5.73 & 4.92 & 1.15 & 5.49 \\
\hline Gangni & 4.80 & - & 5.80 & 5.26 & 1.39 & 5.60 \\
\hline Mean & 4.44 & - & 5.74 & 4.79 & 1.26 & 5.50 \\
\hline \multicolumn{7}{|c|}{ Straw yield $\left(\mathrm{t} \mathrm{ha}^{-1}\right)$} \\
\hline Kushtia & 4.40 & - & 5.40 & 4.85 & 1.86 & 5.30 \\
\hline Bheramara & 5.10 & - & 5.50 & 5.00 & 1.62 & 5.48 \\
\hline Gangni & 5.00 & - & 5.55 & 5.15 & 1.65 & 5.50 \\
\hline Mean & 4.83 & - & 5.48 & 5.00 & 1.71 & 5.43 \\
\hline
\end{tabular}

Rice equivalent yield: It is revealed from Table 3 that the mean rice equivalent yield (REY) of alternate cropping pattern was 13.98 tha $^{-1}$ year-1 $^{-1}$ which was $34 \%$ higher over existing cropping pattern (10.47 tha ${ }^{-1}$ year $\left.^{-1}\right)$. REY of alternate cropping pattern for Kushtia (13.97), Bheramara (13.47) and Gangni (14.51) was 28,38 and $35 \%$ higher against existing cropping pattern (10.88, 9.74 and 10.78 tha $^{-1}$ year $\left.^{-1}\right)$. Higher rice equivalent yield was obtained in alternate cropping pattern due to inclusion of short duration mustard and high yielding varieties as well as improved management technologies. It is evident from the above findings that alternate cropping pattern gave higher yield compared to existing pattern. This finding was supported by Nazrul et al. (2017), Rahman et al. (2015), and Nazrul et al. (2013).

Land use efficiency: Land use efficiency is the effective use of land in a cropping year, which mostly depends on crop duration. The mean land-use efficiency of alternate cropping pattern was 33\% higher (76.44\%) than that of existing pattern $(57.53 \%)$. Alternate cropping pattern utilized the land by 77.53 , 76.44 and $75.34 \%$ for Kushtia, Bheramara and Gangni, respectively, whereas existing pattern utilized the land by $57.53,56.71$ and $58.36 \%$ for Kushtia, Bheramara and Gangni, respectively (Table 3). The land use efficiency was higher in alternate cropping pattern due to cultivation of mustard in the pattern. The similar trend of the findings was cited by Nazrul et al. (2017), Rahman et al. (2015), and Nazrul et al. (2013).

Production efficiency: The mean production efficiency of alternate cropping pattern was found to be $41.38 \mathrm{~kg} \mathrm{ha}^{-1}$ day $^{-1}$ which was $15 \%$ lower over existing 
cropping pattern (48.48 $\mathrm{kg} \mathrm{ha}^{-1}$ day $\left.^{-1}\right)$. Production efficiency of alternate cropping pattern was found to be $38.22,41.42$ and $44.50 \mathrm{~kg} \mathrm{ha}^{-1} \mathrm{day}^{-1}$ for Kushtia, Bheramara and Gangni, respectively, while in existing cropping pattern it was found to be 47.62, 48.05 and $49.77 \mathrm{~kg} \mathrm{ha}^{-1}$ day $^{-1}$ for Kushtia, Bheramara and Gangni, respectively (Table 3 ). The production efficiency was lower in alternate cropping pattern over existing cropping pattern due to lower mustard yield and its medium crop duration.

Labour employment generation: Human labour was employed for land preparation, sowing/transplanting, fertilizing, weeding, pesticide application, harvesting, carrying, threshing, cleaning and drying. It is observed that the mean total number of human labour used for crops cultivation under alternate cropping pattern was 441 man-daysha $^{-1}$ year $^{-1}$ which was generated $26 \%$ higher labour employment than that of existing cropping pattern ( 349 man-days ha $^{-1}$ year $^{-1}$ ) due to inclusion of mustard in alternate cropping pattern (Table 3). Human labour employed to alternate cropping pattern in Kushtia, Bheramara and Gangni was 446, 436 and 442 man-daysha $^{-1}$ year $^{-1}$, respectively while it was 354, 346 and 348 man-daysha ${ }^{-1}$ year $^{-1}$, for Kushtia, Bheramara and Gangni, respectively in existing cropping pattern.

Table 3. Rice equivalent yield, production efficiency, land use efficiency and labour employment of alternate and existing cropping pattern in different MLT sites under OFRD, Kushtia during 2013-2016

\begin{tabular}{l|c|c|c|c|c}
\hline MLT sites & $\begin{array}{c}\text { Cropping } \\
\text { pattern }\end{array}$ & $\begin{array}{c}\text { Rice } \\
\text { equivalent } \\
\text { yield }\left(\text { tha }^{-1}\right)\end{array}$ & $\begin{array}{c}\text { Land use } \\
\text { efficiency }(\%)\end{array}$ & $\begin{array}{c}\text { Production } \\
\text { efficiency } \\
\left(\text { Kg ha }^{-1} \text { day }^{-1}\right)\end{array}$ & $\begin{array}{c}\text { Labour employment } \\
\left(\begin{array}{l}\text { (man-days ha } \\
1^{-1} \text { year }\end{array}\right.\end{array}$ \\
\hline Kushtia & Alternate & 13.97 & 77.53 & 38.22 & 446 \\
& Existing & 10.88 & 57.53 & 47.62 & 354 \\
\multirow{6}{*}{ Bheramara } & Alternate & 13.47 & 76.44 & 41.42 & 436 \\
\multirow{2}{*}{ Gangni } & Existing & 9.74 & 56.71 & 48.05 & 346 \\
& Alternate & 14.51 & 75.34 & 44.50 & 442 \\
\multirow{2}{*}{ Mean } & Existing & 10.78 & 58.36 & 49.77 & 348 \\
& Alternate & 13.98 & 76.44 & 41.38 & 441 \\
\hline
\end{tabular}

Profitability analysis: The study revealed that the mean gross return of alternate and existing cropping pattern was Tk. 2,53,960 ha- and Tk. 1,97,346 ha ${ }^{-1}$, respectively (Table 4 ). The mean gross return of alternate cropping pattern was $29 \%$ higher than that of existing cropping pattern and it might be due to inclusion of mustard and new high yielding varieties. The mean total variable cost of alternate and existing cropping pattern was Tk. 1,54,447 ha- and Tk. 1,22,006 $\mathrm{ha}^{-1}$, respectively. About $32 \%$ higher (Tk. 99,513 ha-1) gross margin was 
calculated at alternate cropping pattern than that of existing cropping pattern (Tk. $75,340 \mathrm{ha}^{-1}$ ). Mean MBCR of alternate cropping pattern was found 1.75 which implied that alternate cropping pattern was $75 \%$ better against existing cropping pattern. The highest MBCR was found in Gangni (1.82) and it followed by Bheramara (1.78) and Kushtia (1.64). According to locations, the gross return of Gangni was slightly higher than other two locations due to higher yields and total variable cost was also higher compared to other two locations due to high labour wages. The gross margin of Kushtia was slightly lower than other two locations due to lower yield.

Table 4. Profitability of alternate and existing cropping pattern in different MLT sites under OFRD, Kushtia during 2013-2016

\begin{tabular}{|c|c|c|c|c|c|c|c|c|}
\hline \multirow[t]{2}{*}{ Parameters } & \multicolumn{4}{|c|}{ Existing Cropping Pattern } & \multicolumn{4}{|c|}{ Alternate Cropping Pattern } \\
\hline & Kushtia & Bheramara & Gangni & Mean & Kushtia & Bheramara & Gangni & Mean \\
\hline $\begin{array}{l}\text { Gross return } \\
\left(\mathrm{Tk} . \mathrm{ha}^{-1}\right)\end{array}$ & 196350 & 196537 & 199150 & 197346 & 251008 & 246961 & 263910 & 253960 \\
\hline $\begin{array}{l}\text { Total variable } \\
\text { cost }\left(\mathrm{Tk} . \mathrm{ha}^{-1}\right)\end{array}$ & 106650 & 126677 & 132691 & 122006 & 140017 & 154960 & 168363 & 154447 \\
\hline $\begin{array}{l}\text { Gross margin } \\
\left(\mathrm{Tk} . \mathrm{ha}^{-1}\right)\end{array}$ & 89700 & 69860 & 66459 & 75340 & 110991 & 92001 & 95547 & 99513 \\
\hline MBCR & & & & & 1.64 & 1.78 & 1.82 & 1.75 \\
\hline
\end{tabular}

\section{Conclusion}

The total crop productivity (in terms of REY), land use efficiency, labour employment, and profitability of alternate cropping pattern [Mustard (Var:BARISarisha-14) - Boro rice (Var:BRRIdhan28) - T.Aman rice (Var:Binadhan-7)] were much higher than that of existing cropping pattern [Fallow - Boro (Var:BRRIdhan28) - T.Aman rice (Var:BRRIdhan39)] due to inclusion of HYV short duration mustard. Thus, mustard can be successfully accommodated in the existing cropping pattern which increased cropping intensity and system productivity with reasonable profitability. This ACP could be demonstrated to exhibited areas in the high and medium high land of Kushtia region in Bangladesh with the collaboration of DAE and BARI.

\section{References}

Alam, M. M. and M. M. Rahman. 2006. Effect of row spacing on seed yield of five varieties of Rapeseed, Bangladesh J. Crop Sci. 17(1): 163-168.

BARC (Bangladesh Agricultural Research Council). 2001. A compendium: Packages of Technologies. A handbook for Farming Systems Development. M. F. Haque, M.A. Razzaque and Abu Akteruzzaman (editors). FSR and D program. Bangladesh Agril. Res. Council. P. 12.

Basak, N. C., J. C. Pandit, and M. H. Khurram. 2007. On-farm evaluation of three mustard varieties under different fertilizer packages. Bangladesh J. Sci. Ind. Res. 42(3): 335-340. 
BBS. 2018. Statistical Year Book of Bangladesh. Bangladesh Bureau of Statistics, Statistics Division, Ministry of Planning, Dhaka, Bangladesh.

BRRI, 2013. Modern Rice Cultivation, 17th Edition. Bangladesh Rice Research Institute (BRRI), Gazipur 1701.

DAE. 2016. Department of Agriculture Extension, Paper presented in the regional research extension review and program planning workshop, Kushtia.

Khan. A. H., H. Rashid, A. Khatun, M. A. Quddus and A. R. Gomosta. 2004. Rice Farming System: improved rice-based cropping systems for different ecosystems. Paper presented at the National Farming Systems Technology Inventory Workshop held at CERDI, Gazipur-1701, July 17-19, 2004.

Mondal, R. I., F. Begum, A. Aziz and S. H. Sharif. 2015. Crop sequences for increasing cropping intensity and productivity. SAARC J. Agri., 13(1):135-147.

Mondal., R. I., M. S. Islam, M. A. J. Bhuiyan, M. M. Rahman, M. S. Alam and M. H. H. Rahman. 2011. Edited. KRISHI PROJUKTI HATBOI (Handbook of Agrotechnology), $5^{\text {th }}$ edition, Bangladesh Agricultural Research Institute, Gazipur 1701, Bangladesh. Pp: 196-206.

Nazrul, M. I., M. K. Hasan, and M. R. I. Mondal. 2017. Production potential and economics of mungbean in rice based cropping pattern in Sylhet region under AEZ 20. Bangladesh J. Agril. Res. 42(3): 413-424.

Nazrul, M. I., M. R. Shaheb, M. A. H. Khan and A. S. M. M. R. Khan. 2013. On-farm evaluation of production potential and economic returns of Potato-Rice Based improved cropping system. Bangladesh J. Agril. Res. 16(2): 41-50.

Rahman, M. M., M. A. Rahaman, M. Ahmed, M. M. Uddin and A. K. Choudhury. 2015. Improvement from mustard-boro-t.aman cropping pattern to mustard-boro-jutet.aman. Bangladesh J. Agril. Res. 40(2): 259-270.

Tomer, S. S and A. S. Tiwari. 1990. Production potential and economics of different crop sequences. Indian J. of Agron. 35(1, 2): 30-35.

Verma, S. P and S. C. Modgal. 1983. Production potential and economics of fertilizer application as resources constraints in maize, wheat crop sequence. Himachal $J$. Agric. Res. 9(2): 89-92. 